\title{
Necrotizing Sarcoid Granulomatosis - is it different from nodular sarcoidosis?
}

\author{
H. H. Popper \\ H. Klemen \\ Th. V. Colby \\ A. Churg
}

\author{
Nekrotisierende Sarkoide Granulomatose - unterscheidet sie sich \\ von der nodulären Sarkoidose
}

\section{Zusammenfassung}

Hintergrund: Die nekrotisierende Sarkoidgranulomatose (NSG) wurde in der ursprünglichen Beschreibung von Averil Liebow als eine Erkrankung zwischen Sarkoidose und Wegener-Granulomatose charakterisiert. Dies vor allem, weil zwei Veränderungen aus beiden Erkrankungen gefunden wurden: konfluierte Sarkoidgranulome wie bei Sarkoidose und infarktartige Areale mit Vaskulitis wie bei Wegener-Granulomatose. In den ursprünglichen Fällen, auf denen Liebow seine Erstbeschreibung aufbaute, fand sich keine extrapulmonale Organbeteiligung, so dass er annahm, dass dies ebenfalls ein Charakteristikum dieser neuen Erkrankung darstellt. Nachfolgende Fallbeschreibungen haben aber auch extrapulmonale Manifestationen gefunden. Bereits in diesen Publikationen wurde diskutiert, ob nicht die NSG eine Variante der Sarkoidose darstellt. Material und Methoden: Zehn Fälle einer NSG von drei verschiedenen Instituten wurden studiert und die histologischen Veränderungen mit denen bei Sarkoidose und insbesondere mit der nodulären Sarkoidose verglichen. Alle diese Fälle wurden auch auf die Präsenz mykobakterieller DNA (Insertionssequenz 6110) untersucht. Ergebnisse und Schlussfolgerungen: Die nodulären Granulomaggregate gleichen denen bei nodulärer Sarkoidose. Die Vaskulitis in der NSG ist eine epitheloidzellige nicht nekrotisierende Vaskulitis, die sich ebenfalls nicht von der granulomatösen Vaskulitis bei Sarkoidose unterscheidet. Eine granulozytäre Vaskulitis, wie sie bei der Wegener-Granulomatose üblich ist, ließ sich nicht darstellen. Das einzige Charakteristikum, dass die NSG von der Sarkoidose unterscheidet, sind die infarktartigen Nekrosen. Die-

\section{Abstract}

Background: Necrotizing sarcoid granulomatosis (NSG) was initially defined as a granulomatosis with features in between sarcoidosis and Wegener's granulomatosis (WG), but without extrapulmonary involvement. Subsequent reports have shown that extrapulmonary involvement does exist, and some have suggested NSG as a variant of sarcoidosis. Material and Methods: We studied 10 cases from 3 institutions, and compared clinical and histologic features with those of nodular sarcoidosis and WG. We have analyzed the 10 cases for mycobacterial chaperonin and for the insertion sequence 6110 by PCR. Results and Conclusions: Nodular aggregates of granulomas in NSG were similar to those seen in nodular sarcoidosis. Granulocytic vasculitis, a hallmark of WG was not seen in any of the NSG cases. Granulomatous vasculitis was a common feature in cases of NSG, and did not differ from that seen in sarcoidosis. The only unique feature of NSG is infarct-like necrosis, induced by the vasculitis, which might also be interpreted as a function of the duration of the vasculitis, leading ultimately to vascular obstruction. NSG based on our morphologic findings is best classified as a variant of nodular sarcoidosis. In contrast to our findings in sarcoidosis mycobacterial DNA was not found in any of the 10 cases. 
se entstehen auf dem Boden der granulomatösen Vaskulitis mit progredientem Gefäßverschluss. Ob dies die Folge einer längerdauernden Vaskulitis mit Lumenobstruktion darstellt, kann letztendlich noch nicht beantwortet werden. Basierend auf unseren Untersuchungen und den vorhandenen Literaturdaten sollte die NSG am besten als Variante der nodulären Sarkoidose interpretiert werden. Im Gegensatz zu unseren Erfahrungen bei Sarkoidose konnte bei keinem der Patienten eine mykobakterielle DNA nachgewiesen werden.

\section{Introduction}

Necrotizing sarcoid granulomatosis (NSG) was initially separated as an entity by A. Liebow [1]. In his initial cases only lung involvement was found. The morphologic features of NSG were considered in between sarcoidosis and Wegener's granulomatosis (WG). The cases showed granulomatous vasculitis and nodular aggregates of epitheloid cell granulomas with foci of central necrosis. No organisms could be found. In subsequent years other reports have shown involvement of non-pulmonary organs, namely eyes, liver, and spleen [2-6]. In addition nodular sarcoidosis has become recognized as a variant of sarcoidosis [7], and those cases showed an overlap with NSG. Since the introduction of video-assisted thoracoscopy and the resultant larger than transbronchial biopsy specimen granulomatous vasculitis is more often seen in sarcoidosis, which again eliminates one feature, thought to be characteristic for NSG [8].

We therefore undertook a study of NSG and compared the features of NSG with sarcoidosis. We specifically looked for features which might unequivocally differentiate NSG from nodular sarcoidosis. Since we found mycobacterial DNA in some of our sarcoidosis cases [9] we assumed that necrosis found in NSG might be associated with a positivity for mycobacterial DNA. Therefore all cases were investigated for mycobacterial DNA using PCR.

\section{Methods and Materials}

Slides and paraffin blocks from lung lesions were retrived from the archives of three Institutions. Cases fullfilling the criteria of NSG were selected by the authors: nodular aggregates of epitheloid cell granulomas, necrosis, and granulomatous vasculitis, and the absence of identifiable infectious etiology by culture and/or special stains. Only ten cases which fullfilled these criteria were collected. H\&E and Movat pentachrome stained sections and acid fast stains were made from formalin fixed paraffin embedded lung tissue blocks. DNA was extracted from paraffin sections, and a PCR for the mycobacterial chaperonin and for the insertion sequence (IS) 6110 was done exactly as described previously [9]. Appropriate negative and positive controls cases were included.

Organ involvement other than pulmonary in these cases were: ocular in 1, liver in 2, spleen in 1, and hilar and mediastinal lymph nodes in 2 cases. In all these cases non-pulmonary involvement was confirmed either by tissue biopsy or CT scan (Table 1).
Table 1 Patient data; na = not available, OLB = open lung biopsy

\begin{tabular}{|c|c|c|c|c|}
\hline $\begin{array}{l}\text { Age } \\
\text { (yr) }\end{array}$ & Sex & lung involvement & $\begin{array}{l}\text { extrapulmonary } \\
\text { involvement }\end{array}$ & unrelated disease \\
\hline 42 & M & single nodule, OLB & ocular & \\
\hline 42 & $\mathrm{~F}$ & 2 nodules, OLB & liver, spleen & \\
\hline 45 & M & single nodule, OLB & no & \\
\hline 49 & $\mathrm{~F}$ & 3 nodules, OLB & pleura, liver & \\
\hline 56 & $\mathrm{~F}$ & 2 nodules, OLB & no & \\
\hline 65 & $\mathrm{~F}$ & 2 nodules, OLB & no & history of breast cance \\
\hline 42 & $\mathrm{~F}$ & mass left UL, OLB & no & na \\
\hline 28 & M & nodules, OLB & no & pleuritis, fever \\
\hline 12 & M & $\begin{array}{l}\text { bilateral nodules } \\
\text { (autopsy) }\end{array}$ & no & $\begin{array}{l}\text { glomerulonephritis, } \\
\text { pleuritis, dead due to } \\
\text { pneumococcal sepsis* }\end{array}$ \\
\hline 66 & M & $\begin{array}{l}\text { bilateral basal } \\
\text { nodules (limited } \\
\text { autopsy) }\end{array}$ & no & na \\
\hline
\end{tabular}

\footnotetext{
* In this case primarily there was a differential diagnosis of hypersensitivity pneumonitis, Wegener's granulomatosis, infectious granulomatosis, necrotizing sarcoid granulomatosis. All former three were excluded clinically and by special stains and culture
}

For comparison six cases of nodular sarcoidosis, characterized by nodular aggregates of epitheloid cell granulomas from $4 \mathrm{~mm}$ to $3 \mathrm{~cm}$ in diameter were chosen from the files of one of the authors (HHP).

\section{Resullts}

In all cases granulomatous nodules and large areas of necroses could be found. In serial sections the contributing pulmonary arteries were demonstrable, all showing different stages of granulomatous vasculitis. The lumina of these arteries were either narrowed or completely obstructed by multiple epitheloid cell granulomas. At the very early stages an infiltrate of lymphocytes, macrophages, few epitheloid and Langhans giant cells without granulomatous organization could be found (Fig. 1), in later stages mature confluent epitheloid cell granulomas predominated, leading to partial or total lumen obstruction (Fig. 2-4). In very late stages the vessel lumina were completely obstructed and only remnants of the inflammatory infiltrate could be found (Fig. 4). Middle sized as well as small sized blood vessels were involved. Necrotic areas were always found around this vasculitis. In all cases non-necrotizing large nodular aggregates of epitheloid cell granulomas were seen in the lung parenchyma (Fig. 5). The amount of Langhans giant cells was variable, ranging from a few to numerous cells. Lung involvement including hilar lymph nodes was present in all cases, whereas extrapulmonary involvement was documented in three cases, including ocular liver and spleen.

Mycobacterial DNA, neither mycobacterial chaperonin, nor insertion sequence 6110 was not found in any of the 10 cases.

In nodular sarcoidosis similar large aggregates of epitheloid cell granulomas as in NSG were seen and also granulomatous vasculitis (Fig. 6). The only difference was the absence of necrosis and vascular lumen obstruction in nodular sarcoidosis. 


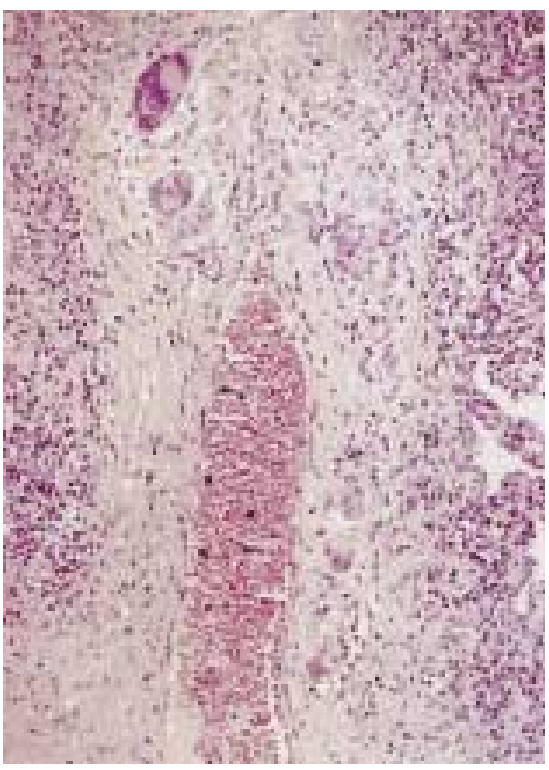

270

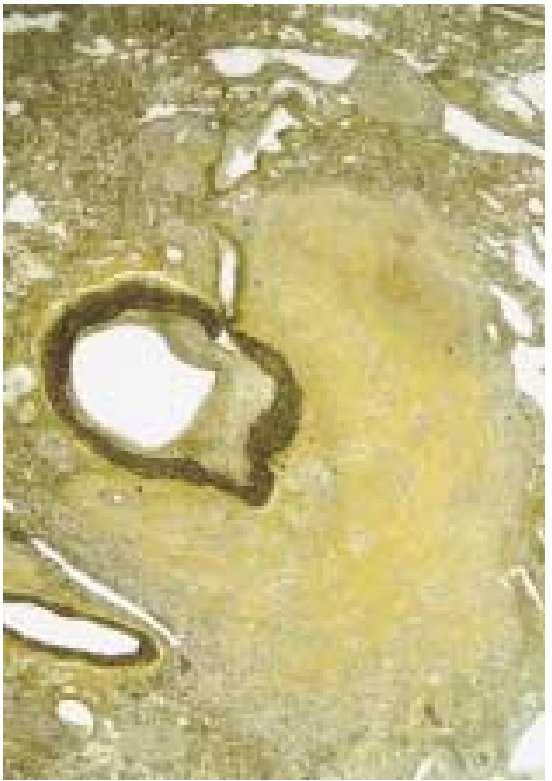

Fig. 3 Granulomatous vasculitis in NSG. The lumen of this large pulmonary artery is partially obstructed, smaller arteries in the surrounding infarct-like necrosis, however, are complete occluded. Epitheloid cell granulomas can be seen within but also outside this necrotic focus. Movat pentachrome, original magnification $\times 40$.

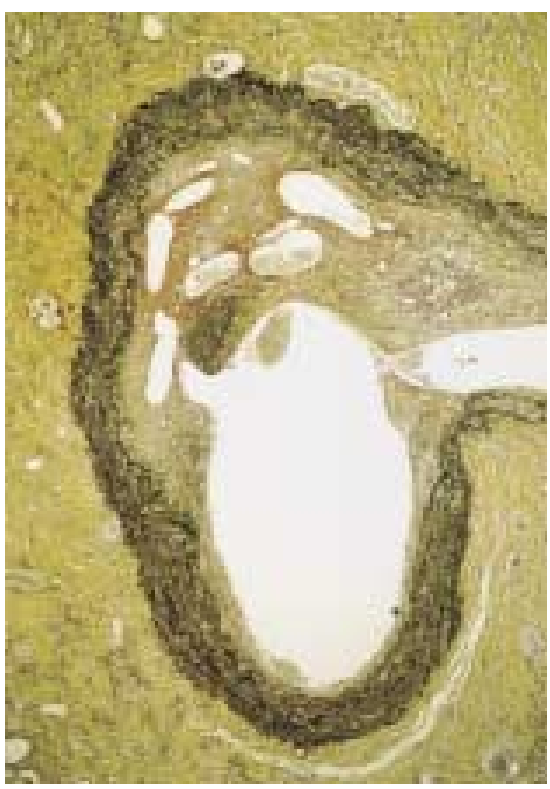

Fig. 2 Granulomatous vasculitis in NSC with epitheloid cell granuloma (upper left). In this late stage vascular lumen is partially obstructed and there is some recanalization; Movat pentachrome, original magnification $\times 65$.

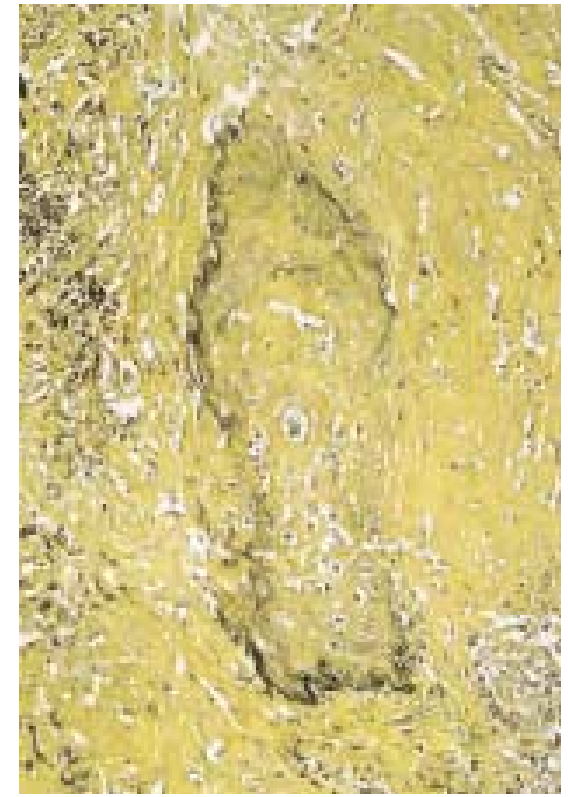

Fig. 4 Late stage of vasculitis: This small pulmonary artery is completely obstructed, remnants of the elastic laminae are visible, but only a few inflammatory cells.

The sourrounding lung parenchyma is completely necrotic. Movat pentachrome, original magnification $\times 100$

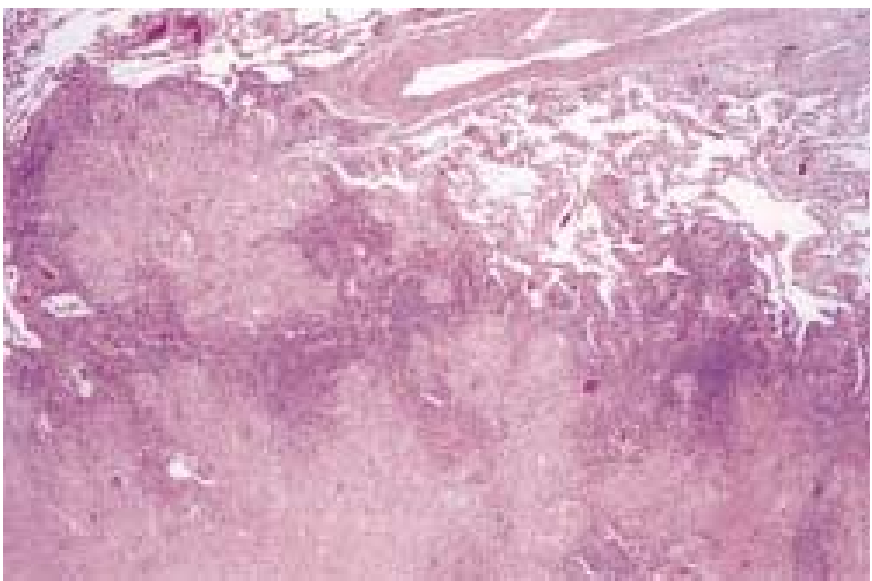

Fig. 5 Nodular aggregates of epitheloid cell granulomas in NSG. H\&E, original magnification $\times 65$.

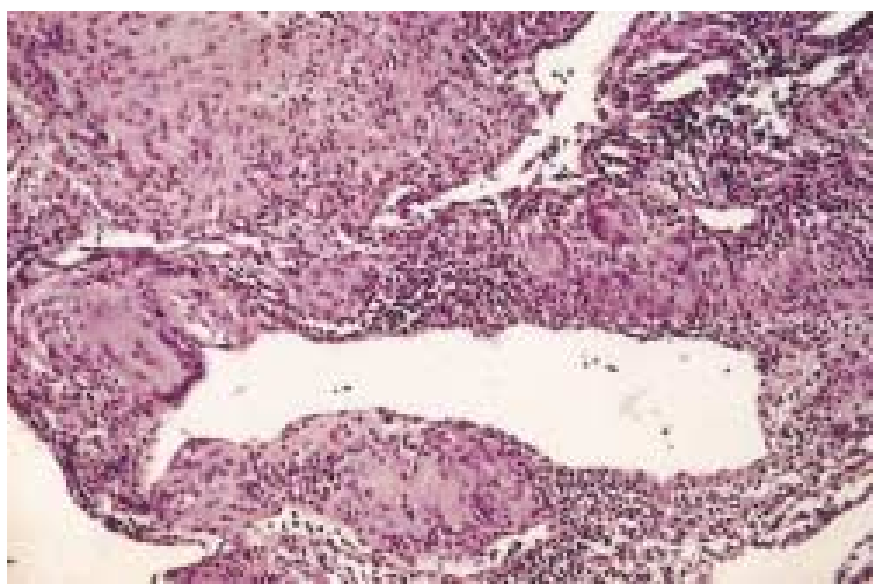

Fig. 6 Granulomatous vasculitis with epitheloid cell granulomas in a case of nodular sarcoidosis; there is no lumen obstruction of this small vein; $\mathrm{H} \& \mathrm{E}$, original magnification $\times 100$. 


\section{Discussion}

NSG was originally defined by Liebow as a lung specific granulomatous disease with vasculitis and necrosis, lying in between sarcoidosis and Wegener's granulomatosis - hence the name [1]. Subsequent reports have shown that NSG is a systemic disease with extrapulmonary involvement. Most often pleural, ocular, liver and spleen lesions were described [2-6].

The invention of video-assisted thoracoscopy has opened the opportunity to review larger lung specimen in sarcoidosis too. This has enabled us to see granulomatous vasculitis in sarcoidosis more often, than anticipated from our experience with transbronchial biopsies and equals that seen in autopsy cases [8], and nodular sarcoidosis, a variant of sarcoidosis with larger, macroscopically visible nodular aggregates of epitheloid cell granulomas is seen more often. This has brought up the question, if NSG is another variant of sarcoidosis.

This has prompted us to retrieve cases from our institutional collections and to compare the features with those of nodular sarcoidosis (NS). Nodular aggregates of epitheloid cell granulomas are found in NSG and in NS. Granulomatous vasculitis too can be seen in NSG and NS, however, complete obstruction of the vascular lumina was only seen in NSG. And necrosis is still the hallmark of NSG. There is a coagulative infarct-like type of necrosis in NSG, which could in most of our cases be attributed to the granulomatous vasculitis with lumen obstruction. Therefore it might be speculated, that NSG is the late stage of NS, when vacular lumen obstruction has occurred and in turn caused infarct-like necrosis. Much rarer necrosis might also be caused by the confluence of degenerative fibrinoid necrosis, sometimes also seen as necrobiotic foci in sarcoidosis.

In addition clinical investigations and comparative clinico-pathologic studies have shown similar immunologic features for NSG and sarcoidosis, for example a dominance of T-helper lymphocytes and a T-helper associated cytokine spectrum in BAL fluid ([10-12]; and personal unpublished observations).

In the differential diagnosis Wegener's Granulomatosis can easily be discerned by the presence of granulocytic vasculitis in the early and lymphocytic vasculitis in the late phase. Bronchocen- tric granulomatosis can be differentiated from NSG by the absence of a granulomatous vasculitis and infarct-like necrosis, and lymphomatoid granulomatosis (angiocentric high grade non-Hodgkin lymphoma) by a vascular infiltrates composed of highly atypical lymphoid cells.

In contrast to previous findings in sarcoidosis, none of the NSG cases had an association for mycobacterial DNA [9], ruling out a Mycobacteria based etiology.

In our opinion NSG should be classified as a variant of sarcoidosis, characterized by extensive granulomatous vasculitis, which in turn causes coagulative necrosis. NSG do no longer qualify as a separate entity.

\section{References}

${ }^{1}$ Liebow AA. The J. Burns Amberson Lecture: Pulmonary angiitis and granulomatosis. Am Rev Respir Dis 1973; 108: 1

2 Singh N, Cole S, Krause P et al. Necrotizing sarcoid granulomatosis with extrapulmonary involvement. Am Rev Respir Dis 1981; 124: 189

${ }^{3}$ Churg A. Pulmonary angiitis and granulomatosis revisited. Hum Pathol 1983; $14: 868$

${ }^{4}$ Dykhuizen RS, Smith CC, Kennedy MM et al. Necrotizing sarcoid granulomatosis with extrapulmonary involvement. Eur Respir J 1997; 10: $245-247$

${ }^{5}$ Chittock DR, Joseph MG, Paterson NA et al. Necrotizing sarcoid granulomatosis with pleural involvement. Clinical and radiographic features. Chest 1994; 106: $672-676$

${ }^{6}$ Brevet F, Hachulla E, Courtin P et al. Systemic form of sarcoid-like necrotizing granulomatosis with ocular, pulmonary and cerebral involvement. Rev Med Interne 1993; 14: 243-248

${ }^{7}$ De Remee RA. Sarcoidosis and Wegener's granulomatosis: a comparative analysis. Sarcoidosis 1994; 11: 7-18

${ }^{8}$ Takemura T, Matsui Y, Saiki S et al. Pulmonary vascular involvement in sarcoidosis: A report of 40 autopsy cases. Hum Pathol 1992; 23: 1216

${ }^{9}$ Popper HH, Klemen H, Höfler G et al. Presence of mycobacterial DNA in sarcoidosis. Hum Pathol 1997; 28: 796-800

${ }^{10}$ Tsukamoto K, Honda A, Kotani I et al. A case of necrotizing sarcoid granulomatosis. Nippon Kyobu Shikkan Gakkai Zasshi 1995; 33: $181-186$

${ }^{11}$ Spiteri MA, Gledhill A, Campbell D et al. Necrotizing sarcoid granulomatosis. Br J Dis Chest 1987; 81: 70 - 75

12 Koss M, Hochholzer L, Feigin D et al. Necrotizing sarcoid-like granulomatosis. Clinical, pathologic, and immunopathologic findings. Hum Pathol 1981; 11 Suppl : 510 